\title{
Student's Self- Efficacy And Their Speaking Skill At Lower Secondary School
}

\author{
Desmaliza $^{a}$, Tria Septiani ${ }^{b}$ \\ ${ }^{a}$ Syarif Hidayatullah State Islamic University Jakarta, Jl. Ir. H. Djuanda 95, Ciputat, Indonesia \\ ${ }^{\mathrm{b}}$ University of Muhammadiyah Tangerang, Jl. P. Kemerdekaan No.33, Cikokol, Tangerang, Banten 15118, Indonesia
}

Corresponding e-mail: desmaliza@uinjkt.ac.id

\begin{abstract}
Although learning English for many years, most students could not be able to practice and speak in the class or out of class. Speaking in English language is very difficult for students and they think that they cannot speak English even though they know that the skill is very important to face the globalization. Various studies shows internal factors play important roles in speaking. One of the factors is self-efficacy (SE). Yet, there has not yet comprehensive study on the correlation between self-efficacy and speaking ability especially in lower secondary level of the students. Therefore, this research intends to find out the relationship between the student's self-efficacy and speaking skill at lower level, at seventh grade students at SMPN 2 Curug, Tangerang. A quantitative method was used. Using a random sampling, 78 students from eight classes were given self-efficacy questionnaire and speaking test. The analysis of correlation revealed that there is a significant correlation between the student's self-efficacy and the student's speaking skill at seventh grade students. Therefore, the English teachers should help the student to increase the student's self- efficacy in speaking skill as it can foster the student's enthusiasm in learning.
\end{abstract}

Keywords: $\quad$ Self-efficacy, Speaking skill

\section{INTRODUCTION}

Speaking skill is a vital element to interact with others. This is in line with Dawes (2008) who states that speaking is very significant for social creature. This skill is also very important in order to face the globalization and internationalization.

In fact, not all of students can easily master speaking skill even though they have been learning English since they were in primary school. According to the interview with English teachers in SMPN 2 Curug, there are some problems in teaching English especially speaking. Most of the students are lazy or lack of speaking practice because they assume that English speaking is the most difficult skill to be learned. They know that when they speak they should speak fluently and consider to use many vocabularies and good grammar appropriately. As a consequence, they underestimate their capability and they are afraid to speak even though they could actually speak. They have the attitude of laughing at their friends if they make mistakes such as wrong or funny pronunciation. The lack of vocabulary also becomes a problem for the students as this lack hinder them from practice their speaking in front of the teachers and their friends. In addition, the students' uncontrolled anxiety affect them fail to speak in English.

There are some factors influencing the student's speaking skill. Latha (2012) examines some factors influencing the student's speaking skill, which are learner inhibition, lack of motivation, lack of subject matter, lack of proper vocabulary, lack of confidence, improper listening skills, poor non-verbal communication, anxiety, strong and quick learners domination in the class, family background, rural background, excessive use of mother-tongue, and lack of proper orientation. Beside these factors, self- 
efficacy also is considered to influence the students' achievement in speaking skill because with the student's belief, self-confidence of students arise.

Self-efficacy in academic setting is a part of Bandura's theory which define self-efficacy as individuals' belief about their ability to execute something related to their selves. "Self-efficacy is a critical determinant of behaviour in school, sports, and social relationship" (Bohlin, et, al., 2012, p. 299). In addition, self-efficacy is determined as the trust that someone possesses and the ability to drive the life and to achieve the target (Communiqué Handout, 2010). Students who have high levels of self-efficacy have a great curiosity, confident and like a challenge. Self-efficacy includes self-control or how to behave. Self-efficacy also affects the tenacity and learning achievement without depending on others. Briefly, self-efficacy could generate student's independence. For instance, a student with high level of self-efficacy has a courage for practice their speaking skill about a topic in front of the class. The student will perform confidently and delivers the material perfectly because he has learned it and has mastered the material before presented.

Bohlin, et. Al. (2012) argued that based on Bandura's thought, there are four factors that could influence someone's level of self-efficacy. They are past performance, modelling, verbal persuasion and physiological states, as presented in Figure 1.

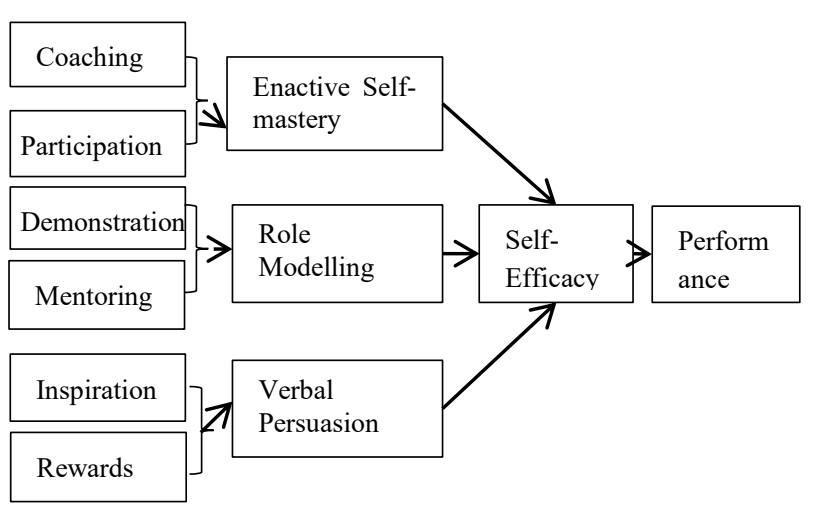

Figure 1

Factors Affecting Self-efficacy (Adapted from Heslin, 1999, as cited in Heslin and Klehe, 2006)

Based on the figure 1, it can be seen that coaching could play a role as an individual's regulation ability to instruct and drill a skill. Another factor, participation as student's activeness to get involved in every activity also becomes an important point to have enactive self-mastery and in result could influence self-efficacy which may lead to a good or bad performance. "Enactive self-mastery is achieved when people experience success at performing at least portions of a task" (Heslin and Klehe, 2006, p. 706). In this case enactive self-mastery is not only about the success experience, but also about achievement or the students' mastery.

Factor which can be a determinant for role modelling is demonstration. It can be defined as an example of doing or using something to go to the purpose they want to achieve. Other factor, mentoring, which part of role modelling has a role as someone's guidance in order to encourage or expand the student's skill in consequence, by demonstrating and mentoring, there will be a role model for the students for doing the task in appropriate way as role-modelling time is happening when the students observe and imitate others' good performance. Inspiration becomes an influential factor for self-efficacy because of its role as a spirit booster. Beside inspiration, reward, in many ways, could be one kind of verbal persuasion. Verbal persuasion can build self-efficacy, because verbal persuasion convinces the student that they able to get the good achievement and it can be support them.

Individuals who have been successful in a given domain in the past are likely to have high selfefficacy. However, when they failed in their previous performance, the level tends to go down. In addition, when individuals see others similar to themselves experience success, they are likely to have high selfefficacy and believe that they can be successful too. In other way, individuals who are told that they can be successful are more likely to believe in their own success and they could develop high self-efficacy. Moreover, physical strength or fatigue can influence the level of self-efficacy (Adeyinka, et.al, 2009, p. 178).

Furthermore, it can be inferred that self-efficacy is the students' belief about their ability to reach the high score in particular subject. The students who have high level of self-efficacy will interpret the difficulty in learning as a challenge that must be passed. Yet, students with low levels of self-efficacy will feel stressed, depressed, anxious, feel hopeless and in result will avoid the difficult task.

The students who study a foreign language with high level of self-efficacy will pass some obstacles in acquiring and producing a foreign language and they will regard the failure as lack of effort, knowledge and skills. Hseih and Schallert (2008, as cited in Burrows, 2009) identify that student's failure in learning foreign language is caused more by lack of 
self-efficacy levels, than on students' mastery itself. This is the same with what Hinton, at, al. (2008) assumption that "If a student's self-efficacy can be increased, his or her resistance to academics may be decreased" (p. 5).

In learning a foreign language the students must believe with their abilities (self-efficacy), because it will affect their behaviours in learning. A hesitancy also can undermine conviction or person's attempt to achieve the goal. The biggest worries of the students capabilities felt in learning English especially in the speaking class is when the exams, because the students are scares the exam result will be bad.

In practicing their English speaking skill, Student's belief is very important because it makes the students motivated and more confidence in their performance. The students who have high levels of self-efficacy in speaking English will be braver to perform than the students with low level of selfefficacy (Khatib and Maroof, 2015). Idrus and Saleh (2008, as cited in Khatib and Maroof, 2015, p. 102) assert that "If lower levels of self-efficacy are identified among students, appropriate actions should be carried out to help boost students' self-efficacy levels through verbal persuasion and encouragement". In fact, even though students have a lot of vocabularies, most of them feel that it is very difficult to speak in front of the class. Therefore, it is very important for teachers to reassure the students, because it will encourage student's self-efficacy in speaking skill. Besides, the students themselves should have or increasing their self-efficacy in speaking skill.

As many research revealed the importance of self-efficacy in higher level of academic setting (e.g. Anggraini, 2014; Amwazir, 2013; Wahyuni, 2015) this research intends to find out the possible relationship between self-efficacy in speaking with the students' speaking performance in lower level of secondary school, junior high school.

\section{METHOD}

\subsection{Population and sample}

The population of this research consist of 8 classes with the total number of 338 students of seventh grade students in SMPN 2 Curug Tangerang while the sample was 78 students by using random sampling as the technique of taking sample. Their age ranged from 11 years old to 15 years old.

\subsection{Research Instrument}

Using a correlational method, there are two types of techniques of collecting the data, which are speaking test and questionnaire of self-efficacy. The speaking test in this research was oral test. It is conducted to assess students' understanding about grammar, vocabulary, comprehension, fluency, and pronunciation. The type of speaking test was interviews. The student were asked one by one in front of the class to address three questions about a picture. The rubric of speaking assessment is adapted from Brown (2004, p.172-173) which consist of five aspects of scoring system: grammar, vocabulary, comprehension, fluency and pronunciation.

To get the data of self-efficacy beliefs, closed questionnaire was distributed to the students. This questionnaire was formulated and designed based on self-efficacy dimensions which are Magnitude, Strength, Generality, Role modelling, and Participation. The questionnaire statement of selfefficacy is adopted from Saeidi and Farshchi's questionnaire (2012, p. 235-239) who measure selfefficacy in speaking of English. The participants were asked to respond to 28 items referring to their selfefficacy in speaking skill with 10 statements for Magnitude, 6 statements for Strength, 4 statements for Generality, 4 statements for Role modelling, and also 4 statements for Participation. After examining the reliability of the instrument, it was found that the value of Alpha Cronbach was " 0,85 " of interval 0,80 $-1,00$, so the instrument is very reliable.

In answering the questions, the students were asked to choose one of the options by giving a checklist. The scores for every response samples were based on the Likert scale which measures the scores of students' self-efficacy in the speaking in 5 scales, ranging from 0 (Strongly Disagree), to 4 (Strongly Agree). 


\section{PROCEDURE}

To find out the correlation between self-efficacy and speaking skill, the data was analyzed by using non parametric statistics, Rank Spearman Correlation, because the the data is not normally distributed. To find out the correlation by using RankSpearman, some steps were used, which were: determining statistic hypothesis, making the Rank, and determining $\rho$ coefficient. The formula of Rank Spearman Correlation written in Riadi (2014, p. 181):

$$
\rho=1-\frac{6 \sum d^{2}}{n\left(n^{2}-1\right)}
$$

Explanation:

$\begin{array}{ll}\rho & \text { : Coefficient of Rank Spearman Correlation } \\ \mathrm{d} \quad \text { : Difference rank } \\ \mathrm{n} \quad \text { : Total number of sample }\end{array}$

\section{RESULTS}

Based on the statistical estimation, the findings show that $\rho$ empiric $(0,755)>$ ptable $(0,225)$. It means that there is a significant correlation between the student's self-efficacy and the student's speaking skill at seventh grade students in SMPN 2 Curug Tangerang. It could be proved from some results of data analysis that the normality test of variable $\mathrm{X}$ result was X2h $(5,144)$ and X2t $(14,067)$. Because X2 $\mathrm{h}<\mathrm{X} 2 \mathrm{t}$, it can be concluded that the data was normally distributed. For variable Y (speaking skill), it was found that $\mathrm{X} 2 \mathrm{~h}$ was 18,2008 and $\mathrm{X} 2 \mathrm{t}$ was 14,067 , and therefore it can be concluded that X2h > $\mathrm{X} 2 \mathrm{t}$. Thus the data was not normall distributed. Then, for homogeneity test of both variables, the analysis found that Fcount $(1,52)>$ Ftable $(1,45)$, so the data was not from homogenous data.

The result of linearity regression test was Fcount $(-0,08)<$ Ftable $(1,72)$, and hence it could be concluded that Ha is rejected and Ho is accepted. In other words, the equation of regression $\mathrm{Y}$ and $\mathrm{X}$ is linear. It was also found that the equation of regression test between the student's self-efficacy and the student's speaking skill was significant. This result obtained from the testing Fcount $(101,07)>\mathrm{F}$ table $(3,96)$, so $\mathrm{H}_{\mathrm{o}}$ is rejected and $\mathrm{Ha}$ is accepted.

\section{DISCUSSION}

Based on the statistical hypothesis of the data, it is revealed that $\rho$ empiric $(0,755)>\rho$ table $(0,225)$, so it can be concluded that $\mathrm{H}_{\mathrm{o}}$ is rejected and $\mathrm{H}_{\mathrm{a}}$ is accepted. It means that there is a significant correlation between self- efficacy and speaking skill. In this research, self-efficacy can influence the student's learning result in speaking in lower secondary level. It can be proved by their scores, where the students with high level of self-efficacy have higher score and the students with low level of self-efficacy have lower score. It can be seen that selfefficacy is very important to construct their reliance of their abilities, because the reliance is the first source of self-confidence of the students. So, if the students have high level of self-efficacy in learning speaking they will be able to perform it well.

This research supports some previous studies such that of Anggraini (2014) who find out that there is significant correlation between students' academic self-efficacy and their engagement in speaking English class in the twelve grade of Senior High School students in Lampung. Another researcher, Amwazir (2013) who published his research on university students in West Sumatra, discovers that the students have high level of self-efficacy in the speaking class and process that can be formed in speaking class is environment selection process. The third researcher, Wahyuni (2015) who held her research in Surabaya University students, draws a conclusion that there is a negative correlation between public speaking anxiety and self-efficacy. She also revealed the possibility for other factors influencing the student's anxiety in public speaking and believes that students who have high level selfefficacy and have high level of speaking skills could make the low level of one's anxiety in public speaking.

\section{CONCLUSIONS}

It can be concluded that there is a significant correlation between the student's self-efficacy and the student's speaking skill at the seventh grade students of SMPN 2 Curug, Tangerang. The findings of this research suggest that student perception on 
their own self-efficacy plays a significant role in predicting students' performance in practising their English, especially in speaking. Therefore, it is very important for teacher to help students to increase their students' self-efficacy and keep maintaining it to enhance students' English speaking skill in the future.

As other research, this research has several limitations. This research was conducted only in one school. Besides, the respondents were only the seventh grade students, and therefore, it is quite difficult to define surely if self-efficacy can influence the student's achievement in learning speaking widely.

\section{REFERENCES}

Amwazir, A. (2013) Students' Self-Efficacy in Speaking Class at the First Year english Department Students Of Stkip Pgri Suatera Baratin Academic Year 2012/2013.

Bohlin, L., Durwin, C.C., \& Weber, M. R. (2012). EdPsych Modules. New York: Mc.Graw-Hill Companies.

Brown, H. D. (2004). Language Assessment. Principle and Classroom Practices. New York: Longman.

Burrows, L. (2009). Assessing Self-Efficacy: Constructing a Scale. Kinki University English Journal, 4, p. 1-12. Accessed on November 22, 2015, from https://scholar.google.co.id/scholar?q=Burrows $\% 2 \mathrm{C}+\mathrm{L} .+\% 2820$ 09\%29.+Kinki+University+English+Journal.+A ssessing + SelfEfficacy $+\% 3 \mathrm{~A}+$ Constructing $+\mathrm{a}+\mathrm{S}$ cale. $+\& b t n G=\& h l=i d \& a s \_s d t=0 \% 2 C 5$.

Authors. (2010). Self-Efficacy: Helping Children Believe They Can Succeed. Communiqué Handout, 39(3), pp. 1-4. Accessed on November 21, 2015, from https://www.google.com/search?q=\%2BCommu niqu $\% \mathrm{C} 3 \% \mathrm{~A} 9 H a n d o u t \% 29+$ selfehelping childr en believe they can suceed\&ie $=$ utf8\&oe $=$ utf8 $\# \mathrm{q}=$ CommuniquC $3 \% \mathrm{~A} 9+$ Handout $\% 29+$ selfeffi cacy_helping children believe they can sucee d.

Dawes, L. (2008). The essential Speaking and Listening: Talk for Learning at KEY STAGE 2. USA and Canada: Taylor and Francis e-Library.
Hackathorn, J., Solomon, E,D., Blankmeyer, K.L., Tennial, R.E,. and Garczynski, A, M. (2011). Learning by Doing: An Empirical Study of Active Teaching Techniques. The Journal of Effective Teaching an online journal devoted to teaching excellence, 11(2), pp. 40-54. Accessed on March 8, 2016, from https://www.google.co.id/?gws_rd=cr\&ei=P6H eVtHwKo qXuA Sk1oWoBg\#q $=$ demonstration + meaning + journ al+pdf.

Heslin, P. A. \& Klehe, U.C. (2006). Encyclopedia of Industrial/ Organizational Psychology. Selfefficacy. 2, pp. 705-708. Accessed on November 17, 2015, from http://papers.ssrn.com/ol3/ papers.cfm?abstractid $=1150858$.

Hinton, L., Simpson, G., \& Smith, D. (2008). Increasing Self-efficacy Beliefs in Middle School Students Using Quantum Learning Techniques. Piedmont College. Accessed on March 18, 2016, from https://www.google.com/ search? $=$ Increasing + Selfefficacy+Beliefs + in + Middle + School + Students + Using + Quantum + Le arning + Techniques + Lauren+Hinton $\% 2 \mathrm{C}+$ Glen $\mathrm{n}+$ Simpson $\% 2 \mathrm{C}+$ and + Denecia + Smith \&ie $=$ utf$8 \&$ oe $=$ utf- 8 .

Khatib, F. M. M. and Maroof, N. (2015). Self-Efficacy Perception of Oral Communication Ability among English as a Second Language (ESL) Technical Students. Malaysia: University of Malaysia National. Accessed on December 10, 2015, from https://www.google.com $/$ search?q=Selfefficacy + perception + of + oral + co mmunication + ability + among + English $+\mathrm{as}+\mathrm{a}+\mathrm{Se}$ cond + Language $+($ ESL $)+$ Technical + Students $+F$ aridatul + Mastura + Mohamed + Khatiba $+\% 26+$ No oreiny+Maarofb*+aPoliteknik + Merlimau $\% 2 \mathrm{C}+$ Melaka\%2C+Malaysia+bFakulti+Pendidikan\% 2C+Universiti+Kebangsaan+Malaysia $\% 2 \mathrm{C} 4360$ 0+Bangi $\% 2 \mathrm{C}+$ Selangor $\% 2 \mathrm{C}+$ Malaysia + Abstra ct\&ie $=$ utf- $8 \&$ oe $=$ utf -8 .

Latha, B. M. (2012, September). Teaching English as A Second Language: Factors Affecting Learning Speaking Skills. IJERT, 1(7), pp. 1-6. Accessed on November 21, 2015, from http://www.ijert.org/view-pdf/942/teachingenglish-as-a-second-language-factors-affectinglearning-speaking-skills.

Riadi, E. (2014). Metode Statistika Parametrik \& Nonparametrik. Tangerang: Pustaka Mandiri. 
Saedi, M \& Farshchi, E. E (2012). The Effect of Teaching Communication Strategies on Iranian EFL Learners' Speaking Self- efficacy in Content-based Courses. Iran: Islamic Azad University. Accessed on February 15, 2016, from https://www.google.com/search?q=speaking+sel f+efficacy +

survey\&biw $=1366 \&$ bih $=641 \&$ noj $=1 \&$ ei $=\mathrm{M} \_\mathrm{H}$ BVoOODMW5uATCmY_YCA\&start $=30 \&$ sa $=$ N.

Wahyuni, E. (2015). Hubungan Self-Effecacy dan Keterampilan Komunikasi dengan Kecemasan Berbicara di Depan Umum. Jurnal Komunikasi Islam, 5(1). Surabaya: Asosiasi Profesi Dakwah Islam Indonesia. 